\title{
HUBUNGAN USIA IBU HAMIL BERISIKO DENGAN KEJADIAN PREEKLAMPSIA/EKLAMPSIA DI RSU HAJI SURABAYA PERIODE 1 JANUARI 2013 - 31 DESEMBER 2013
}

\author{
Ayu Putri Haryani ${ }^{1}$, Moch Maroef $^{2}$, Sri Adilla $\mathbf{N}^{3}$
}

Fakultas Kedokteran Universitas Muhammadiyah Malang, J1. Bendungan Sutami 188A, Malang, Jawa Timur, 65145, Indonesia, +62341 551149

\begin{abstract}
ABSTRAK
Hubungan Usia Ibu Hamil Berisiko dengan Kejadian Preeklampsia/Eklampsia di RSU Haji Surabaya Periode 01 Januari 2013-31 Desember 2013. Preeklampsia/eklampsia menjadi penyulit pada 5-10\% kehamilan di dunia.Salah satu faktor risiko preeklampsia/eklampsia adalah usia $<20$ tahun atau $>35$ tahun. Usia ibu $<20$ tahun dipengaruhi oleh immaturitas biologis, kehamilan tidak diinginkan, asuhan ante natal inadekuat, dan kecukupan nutrisi yang buruk. Usia $>35$ tahun berubungan dengan kerusakan sel endothel pembuluh darah karena proses penuaan. Penelitian ini bertujuan mengetahui hubungan usia ibu hamil berisiko dengan kejadian preeklampsia/eklampsia di RSU Haji Surabaya periode 01 Januari 2013-31 Desember 2013. Penelitian bersifat Observasional Analitik dengan pendekatan secara Cross Sectional Study. Sampel dalam penelitian ini adalah rekam medis ibu hamil yang terdiagnosis preklampsia/eklampsia di RSU Haji Surabaya peridoe 01 januari 2013-31 Desember 2013.Teknik pengambilan sampel menggunakan total sampling. Dan dianalisis dengan uji Chi-square. Hasil Uji Chi-Square didapatkan nilai $\mathrm{p}=0,000$. Nilai ini lebih kecil dari $\alpha=0,05$ dan $R R<1(R R=2,146)$. Sehingga dapat disimpulkan bahwa terdapat hubungan antara usia ibu hamil berisiko dengan kejadian preeklampsia/eklampsia. Wanita pada kelompok usia $<20$ tahun dan $>35$ tahun lebih berisiko mengalami Preeklampsia daripada kelompok usia 20-35 tahun. Kesimpulan ada hubungan antara usia ibu hamil berisiko dengan kejadian preeklampsia/eklampsia di RSU Haji Surabaya periode 01 Januari 2013-31 Desember 2013.
\end{abstract}

\section{ABSTRACT}

Relation Between Risky Maternal Age with The Happening of Preeclampsia/Eclampsia in RSU Haji Surabaya Period of 1 January 2013-31 December 2013. Preeclampsia/ eclampsia complicate 5-10\% pregnancy in the world. One of the risk factor of preelampsia/eclampsia is maternal age below 20th or above 35th. Maternal age below 20th being influenced by biological immaturity, unintended pregnancy, inadequate perinatal care and poor maternal nutrition. Maternal age above 35th is related with the failure of endothelial cell during aging process. Purpose to knowing relationship between risky maternal age with the happening of preeclampsia/ eclampsia in RSU Haji Surabaya period of 1 January 2013-31 December 2013. This study was an observasional analytic with cross sectional study approach. The sample was the medical record of pregnant woman whom diagnosed with preeclampsia/ eclampsia with total sampling as the sampling techniques and analyzed with Chi-square test. Results Chi-Square analysis of risky maternal age with the happening of preeclampsia/ eclampsia got the significant value smaller than 0,05 (P value $=0,000)$ and $R R$ bigger than 1 (RR= 2,146). It showed that there is relationship between risky maternal age and the happening of preeclampsia/eclampsia. woman below 20th and above 35th had more risk of preeclampsia/eclampsia compared with woman at 20-35th. Conclusion, there was relationship between risky maternal age with the happening of preeclampsia/ eclampsia in RSU Haji Surabaya period of 1 January 2013-31 December 2013.

Key words : Preelampsia, eclampsia, age, risk factor

\section{PENDAHULUAN}

Preeklampsia/eklampsia menjadi penyulit pada 5-10\% kehamilan di dunia (Sutopo,2011). Di negara berkembang, preeklampsia/eklampsia menjadi $15-20 \%$ penyebab utama kematian ibu (Shamsi, 2013). Sedangkan di Indonesia, preeklampsia/eklampsia merupakan penyebab 25\% kematian ibu setelah perdarahan postpartum (Kemenkes RI. 2011). Dan di Jawa Timur, tercatat preeklampsia/eklampsia menjadi salah satu dari 3 penyebab utama kematian ibu pada tahun 2010 yaitu sebanyak 26,92\%, padatahun 2011 meningkat menjadi 27,27\% dan pada tahun 2012 sebanyak 34,88\% (Dinkes, 2013).
Banyak penelitian telah dilakukan untuk mengidentifikasi faktor resiko, etiologi, dan pencegahan preeklampsia/eklampsia. Namun, hingga saat ini belum ditemukan upaya pasti untuk mencegah terjadinya preeklampsia-eklampsia.Oleh karena itu, pencegahan preeklampsia/eklampsia dengan waspada terhadap faktor resiko preeklampsia/eklampsia penting dilakukan (Prawirohardjo, 2010). Data di VK IRD RSU Dr. Soetomo Surabaya menunjukkan bahwa kejadian preeklampsia berdasarkan usia adalah sebesar $38.83 \%$ pada kelompok usia $<20$ tahun dan $42.26 \%$ pada kelompok usia $>35$ tahun. 
Penelitian yang dilakukan oleh Rozanna (2009) menunjukkan bahwa ibu yang berusia $>35$ tahun merupakan faktor risiko terhadap kejadian preeklampsia dengan nilai OR 2.75. Hasil yang sama juga didapatkan oleh Utama (2008) menunjukkan adanya hubungan yang bermakna antara usia ibu melahirkan dengan kejadian preeklampsia. Resiko kejadian preeklampsia ibu melahirkan dengan umur $<20$ tahun dan $>35$ tahun adalah 3,67 kali lebih besar. Namun, berdasarkan hasil penelitian yang dilakukan oleh Rozikhan (2007) di RS Dr. H Soewondo Kendal dan Indra Dewi (2012) di RS Syaiful Anwar Malang menyimpulkan bahwa tidak didapatkan hubungan yang signifikan antara usia dengan angka kejadian preeklampsia.

Karena itu, berdasarkan hasil diatas, penulis ingin mengetahui lebih lanjut hubungan usia ibu hamil berisiko ( $<20$ tahun dan $>35$ tahun) dengan kejadian preeklampsia/ eklampsia di Rumah Sakit Umum Haji Surabaya periode 1 Januari 2013-31 Desember 2013. Penelitian ini diharapkan dapat memberikan manfaat menambah pengetahuan masyarakat tentang preeklampsia/eklampsiadan faktor risikonya sehingga masyarakat dapat meningkatkan kewaspadaan terhadap faktor risiko yang dimiliki sehingga dapat menekan angka kejadian preeklampsia/eklampsia serta untuk memberikan masukan dan informasi atau data yang berkaitan dengan angka kejadian preeklampsia/eklampsia.

\section{METODE}

Penelitian ini merupakan penelitian observasional analitik dengan menggunakan rancangan penelitian metode Cross Sectional Study untuk mengetahui hubungan usia ibu hamil berisiko dengan kejadian preeklampsia/eklampsia di RSU Haji Srabaya periode 1 Januari 2013-31 Desember 2013. Penelitian ini dilakukan di RSU Haji Surabaya pada bulan februari 2014.

Populasi dari penelitian ini adalah rekam medis seluruh ibu hamil di RSU Haji Surabaya. Sampel dalam penelitian ini adalah rekam medis ibu hamil yang terdiagnosis preeklampsia/ eklampsia di RSU Haji Surabaya periode 1 Januari 2013-31 Desember 2013 yang memenuhi kriteria inklusi. Tehnik pengambilan sampel dalam penelitian ini dengan menggunakan Total Sampling.

Kriteria inklusi pada penelitian ini adalah ibu hamil yang terdiagnosis preeklampsia/eklampsia di RSU Haji Surabaya periode 1 januari 2013-31 Desember 2013, ibu hamil tanpa preeklampsia/eklampsia di RSU Haji Surabaya periode 1 januari 2013 - 31 Desember 2013 dan ibu hamil dengan usia kehamilan $>20$ minggu.

Sedangkan kriteria eksklusi pada penelitian ini adalah ibu hamil yang memiliki riwayat preeklampsia pada keluarga, ibu hamil dengan kehamilan ganda, ibu hamil yang memiliki riwayat hipertensi, ibu hamil yang memiliki riwayat diabetes mellitus, dan ibu hamil yang memiliki riwayat penyakit ginjal.

Alat dan bahan yang digunakan dalam penelitian ini adalah data sekunder dari rekam medis ibu hamil yang terdiagnosis preeklampsia/eklampsia dan tanpa preeklampsia/eklampsia di kamar bersalin RSU Haji Surabaya periode 1 januari 2013 - 31 Desember 2013.
Analisis data yang digunakan dalam penelitian ini adalah metode Chi-Square karena untuk mengetahui adanya hubungan antara usia ibu hamil berisiko dengan kejadian preeklampsia/ eklampsia.

\section{HASIL DAN PEMBAHASAN}

\section{Deskripsi Karakteristik Sampel Penelitian}

Telah dilakukan penelitian terhadap 367 wanita yang memenuhi kriteria inkusi, yaitu wanita dengan usia kehamilan > 20 minggu di RSU Haji Surabaya periode 01 januari 2013 - 31 Desember 2013. Berdasarkan penelitian yang telah dilakukan, didapatkan data jumlah responden terbanyak adalah pada kelompok usia 20-35 tahun yaitu sebanyak 277 wanita $(75 \%)$, dan jumlah responden paling sedikit adalah pada kelompok $<20$ tahun yaitu sebanyak 22 wanita $(6 \%)$.

Pada wanita dengan usia kehamilan $>20$ minggu di kelompok usia $<20$ tahun didapatkan paling banyak tediagnosis normal yaitu sebanyak 17 wanita $(77,27 \%)$. Pada kelompok usia 20 - 35 tahun didapatkan paling banyak terdiagnosis normal yaitu sebanyak 201 wanita $(71,5 \%)$. Sedangkan pada kelompok usia > 35 tahun didapatkan paling banyak terdiagnosis preeklampsia/eklampsia yaitu sebanyak 53 wanita (72,6\%).

Tabel 1 Distribusi Ibu Hamil dengan Usia Kehamilan > 20 minggu Berdasarkan Usia.

\begin{tabular}{ccc}
\hline Usia & PE/E & Persentase $(\%)$ \\
\hline$<20$ tahun & 22 & 58,5 \\
$20-35$ tahun & 281 & 74,7 \\
$>35$ tahun & 72 & 19 \\
\hline Total & 376 & 100
\end{tabular}

Sumber : Data Rekam Medik RSU Haji Surabaya

Tabel 2 Distribusi Ibu Hamil dengan Usia Kehamilan > 20 minggu Berdasarkan Usia dan Diagnosis

\begin{tabular}{lccc}
\hline \multirow{2}{*}{ Usia } & \multicolumn{2}{c}{ Kejadian Penyakit } & \multirow{2}{*}{ Total } \\
\cline { 2 - 3 } & PE/E & Non PE/E & \\
\hline$<20$ tahun & 5 & 17 & 22 \\
$20-35$ tahun & 80 & 201 & 281 \\
$>35$ tahun & 53 & 20 & 73 \\
\hline \multicolumn{3}{c}{ Total } & 376 \\
\hline Sumber : Data Rekam Medik RSU Haji \\
Surabaya
\end{tabular}

Sehingga dari keseluruhan responden yang memenuhi kriteria inklusi didapatkan 138 wanita terdiagnosis preeklampsia/eklampsia. Setelah menyingkirkan kriteria eksklusi, didapatkan 129 sampel penelitian. Dan berdasarkan data tersebut, dilakukan analisis data untuk mengetahui hubungan usia ibu hamil berisiko $(<20$ tahun atau $>35$ tahun) dengan kejadian preeklampsia/eklampsia di RSU Haji Surabaya periode 01 januari 2013 - 31 Desember 2013.

\section{Deskripsi Karakteristik Sampel Penelitian Berdasarkan Usia}

Berdasarkan hasil penelitian, diperoleh data 129 wanita yang terdiagnosis preeklampsia/eklampsia di RSU Haji Surabaya periode 01 januari 2013-31 Desember 2013 yang memenuhi kriteria inklusi dan eksklusi. Jumlah terbanyak 
adalah pada kelompok usia 20-35 tahun sebanyak 76 wanita $(58,9 \%)$, dan jumlah paling sedikit adalah pada kelompok usia $<20$ tahun sebanyak 5 wanita $(3,8 \%)$.

\section{Deskripsi Karakteristik Sampel Penelitian Berdasarkan Diagnosis}

Berdasarkan hasil penelitian didapatkan informasi bahwa pada dari 129 wanita ya terdiagnosis preeklampsia/ eklampsia, pada kelompok usia $<20$ tahun paling banyak terdapat 3 wanita $(60 \%)$ terdiagnosis preeklampsia ringan, pada kelompok usia 20-35 tahun paling banyak terdapat 38 wanita $(50 \%)$ terdiagnosis preeklampsia berat. Sedangkan pada kelompok usia $>35$ tahun paling banyak terdapat 36 wanita $(75 \%)$ terdiagnosis preeklampsia berat.

Tabel 3 Deskripsi Karakteristik Sampel

Penelitian Berdasarkan Usia

\begin{tabular}{ccc}
\hline Usia & PE/E & Persentase $(\%)$ \\
\hline$<20$ tahun & 5 & 3,8 \\
$20-35$ tahun & 76 & 58,9 \\
$>35$ tahun & 48 & 37,2 \\
\hline Total & 129 & 100
\end{tabular}

Sumber : Data Rekam Medik RSU Haji

Surabaya

\section{Deskripsi karakteristik Sampel Penelitian Berdasarkan Paritas}

Berdasarkan hasil penelitian, didapatkan informasi bahwa pada kelompok usia $<20$ tahun paling banyak berstatus nullipara yaitu sebayak 4 wanita $(80 \%)$. Pada kelompok usia 20-35 tahun paling banyak berstatus nullipara yaitu sebanyak 36 wanita $(47,3 \%)$ dan pada kelompok usia $>35$ tahun paling banyak berstatus multipara yaitu sebanyak 26 wanita $(54 \%)$.

\begin{tabular}{ccccc}
\multicolumn{5}{c}{ Tabel 5.4. Deskripsi karateristik sampel Penelitian Berdasarkan Diagnosis } \\
\cline { 2 - 4 } Usia & PER & Diagnosis & Total \\
\hline \multirow{2}{*}{$<20$ tahun } & 3 & 2 & 0 & 5 \\
& $60 \%$ & $40 \%$ & $0 \%$ & $100 \%$ \\
$20-35$ tahun & 36 & 38 & 2 & 76 \\
& $47,30 \%$ & $50 \%$ & $2,70 \%$ & $100 \%$ \\
$>35$ tahun & 12 & 36 & 0 & 48 \\
& $25 \%$ & $75 \%$ & $0 \%$ & $100 \%$ \\
\hline Total & \multicolumn{4}{c}{367} \\
\hline Sumber : Data Rekam Medik RSU Haji Surabaya
\end{tabular}

\section{Deskripsi karakteristik Sampel Penelitian Berdasarkan Tingkat Pendidikan}

Berdasarkan penelitian yang dilakukan, didapatkan informasi bahwa dari 129 sampel penelitian jumlah terbanyak adalah pada tingkat pendidikan sekolah menengah atas atau sederajat yaitu sebanyak 53 wanita $(41 \%)$ dan paling sedikit pada tingkat pendidikan sekolah dasar dan perguruan tinggi yaitu masing - masing sebanyak 23 wanita $(17,8 \%)$.
Tabel 5 Deskripsi Karakteristik Sampel Penelitian Berdasarkan Paritas

\begin{tabular}{llcc}
\hline \multicolumn{1}{c}{ Usia } & \multicolumn{1}{c}{ Paritas } & PE/E & $\begin{array}{c}\text { Persentase } \\
(\%)\end{array}$ \\
\hline$<20$ & Nullipara & 4 & 80 \\
tahun & Primipara & 1 & 20 \\
dan & Multipara & 0 & 0 \\
$>35$ & Grandemultipara & 0 & 0 \\
tahun & Jumlah & 5 & 100 \\
& Nullipara & 36 & 47,3 \\
Usia 20- & Primipara & 30 & 39,4 \\
35 & Multipara & 9 & 11,8 \\
tahun & Grandemultipara & 1 & 1,3 \\
& Jumlah & 76 & 100 \\
& Nullipara & 5 & 10,4 \\
Usia $>$ & Primipara & 17 & 35,4 \\
35 & Multipara & 26 & 54 \\
tahun & Grandemultipara & 0 & 0 \\
& Jumlah & 48 & 100 \\
\hline Total & & 129 & 100 \\
\hline Sumber : Data Rekam Medik RSU Haji Surabaya
\end{tabular}

\section{Hubungan Usia Ibu Hamil Berisiko dengan Kejadian Preeeklampsial Eklampsia}

Untuk mengetahui ada atau tidaknya hubungan antara usia ibu hamil berisiko dengan kejadian preeklampsia/ eklampsia di RSU Haji Surabaya Periode 01 januari 2013 31 Desember 2013, maka dibentuk tabulasi silang (crosstabs) yang dapat menggambarkan penyebaran data secara lebih terinci, degan mambandingkan antar kelompok usia sebagaimana disajikan sebagai berikut :

Tabel 7 Hubungan Usia Ibu Hamil berisiko $(<20$ tahun dan $>35$ tahun) dengan Kejadian

Preeklampsia/Eklampsia

\begin{tabular}{|c|c|c|c|}
\hline \multirow[b]{2}{*}{ Usia } & \multicolumn{2}{|c|}{ Kejadian Penyakit } & \multirow[b]{2}{*}{ Total } \\
\hline & $\mathrm{PE} / \mathrm{E}$ & $\begin{array}{c}\text { Non } \\
\mathrm{PE} / \mathrm{E}\end{array}$ & \\
\hline $\begin{array}{l}<20 \text { tahun dan } \\
>35 \text { tahun }\end{array}$ & 53 & 37 & 90 \\
\hline 20-35 tahun & 76 & 201 & 277 \\
\hline Total & & & 376 \\
\hline
\end{tabular}

Pada pengujian di atas didapatkan nilai $\mathrm{p}=0,000$. Nilai ini lebih kecil dari $\alpha=0,05$ sehingga dapat disimpulkan bahwa terdapat hubungan yang bermakna antara Usia ibu hamil berisiko dengan kejadian Preeklampsia/eklampsia.

Perhitungan Relative Risk sebesar 2,146 dan lebih besar dari 1 menunjukkan bahwa kelompok usia $<20$ tahun dan $>35$ tahun lebih beresiko mengalami preeklampsia/ eklampsia dari pada kelompok usia 20-35 tahun. 
Tabel 6 Deskripsi Karakteristik Sampel Penelitian Berdasarkan Tingkat Pendidikan

\begin{tabular}{ccc}
$\begin{array}{c}\text { Tingkat } \\
\text { pendidikan }\end{array}$ & Jumlah & $\begin{array}{c}\text { Persentase } \\
(\%)\end{array}$ \\
\hline SD & 23 & 17,8 \\
SMP & 30 & 23,2 \\
SMA & 53 & 41,2 \\
PT & 23 & 17,8 \\
Total & 129 & 100 \\
Sumber : Data Rekam Medik RSU Haji \\
Surabaya
\end{tabular}

Perhitungan Relative Risk sebesar 0,322 dan lebih kecil dari 1 menunjukkan bahwa kelompok usia $>35$ tahun lebih beresiko mengalami Preeklampsia/eklampsia daripada kelompok usia $<20$ tahun.

Tabel 8 Perbandingan Risiko Usia $<20$ tahun dengan Usia $>35$ tahun Terhadap Kejadian P reeklampsia/ Eklampsia

\begin{tabular}{rccc}
\hline \multirow{2}{*}{ Usia } & \multicolumn{2}{c}{ Kejadian Penyakit } & \\
\cline { 2 - 3 } & \multirow{2}{*}{$\mathrm{PE} / \mathrm{E}$} & $\begin{array}{c}\text { Non } \\
\text { Total }\end{array}$ & $\mathrm{PE} / \mathrm{E}$ \\
$<20$ tahun & 5 & 17 & 22 \\
$>35$ tahun & 48 & 20 & 68 \\
Total & & & 90
\end{tabular}

Sumber : Data Rekam Medik RSU Haji Surabaya

Perhitungan Relative Risk sebesar 0,828 dan lebih kecil dari 1 menunjukkan bahwa kelompok usia 20-35 tahun lebih beresiko mengalami Preeklampsia/eklampsia daripada kelompok usia $<20$ tahun.

Tabel 9 Perbandingan Risiko Usia $<20$ tahun dengan Usia 20-35 tahun Terhadap Kejadian Preeklampsia/Eklampsia

\begin{tabular}{cccc}
\hline \multirow{2}{*}{ Usia } & \multicolumn{2}{c}{ Kejadian Penyakit } & \\
\cline { 2 - 3 } & $\mathrm{PE} / \mathrm{E}$ & $\begin{array}{c}\text { Non } \\
\text { TE } / \mathrm{E}\end{array}$ & \\
\hline 20 tahun & 5 & 17 & 22 \\
$20-35$ tahun & 76 & 201 & 277 \\
Total & & & 299
\end{tabular}

Sumber : Data Rekam Medik RSU Haji Surabaya

Tabel 10 Perbandingan Risiko Usia 20-35 tahun dengan Usia > 35 tahun Terhadap Kejadian Preeklampsia / Eklampsia

\begin{tabular}{cccc}
\hline \multirow{2}{*}{ Usia } & \multicolumn{2}{c}{ Kejadian Penyakit } & \\
\cline { 2 - 3 } & $\mathrm{PE} / \mathrm{E}$ & $\begin{array}{c}\text { Non } \\
\text { TE/E }\end{array}$ & \\
20-35 tahun & 76 & 201 & 277 \\
>35 tahun & 48 & 20 & 68 \\
\hline Total & & & 345
\end{tabular}

Sumber : Data Rekam Medik RSU Haji Surabaya

Perhitungan Relative Risk sebesar 0,389 dan lebih kecil dari 1 menunjukkan bahwa kelompok usia $>35$ tahun lebih beresiko mengalami Preeklampsia daripada kelompok usia $20-35$ tahun.

\section{Hubungan Paritas dengan Kejadian Preeeklampsial Eklampsia}

Pada pengujian diatas didapatkan pada kelompok usia berisiko ( $<20$ tahun dan $>35$ tahun) didapatkan nilai $\mathrm{p}=$ 0,022 . Nilai ini lebih kecil dari á $=0,05$ dengan nilai korelasi -0,236 sehingga dapat disimpulkan bahwa terdapat hubungan yang bermakna antara paritas dengan kejadian preeklampsia/ eklampsia. Semakin tinggi paritas maka semakin tinggi pula peluang mengalami preeklampsia/eklampsia. Sedangkan pengujian pada kelompok usia reproduksi sehat (20-35 tahun) didapatkan nilai $\mathrm{p}=0,371$. Nilai ini lebih besar dari $\alpha=0,05$. Sehingga dapat disimpulkan bahwa tidak terdapat hubungan yang bermakna antara paritas dengan kejadian reeklampsia/eklampsia.

Pada penelitian ini, pada kelompok usia $<20$ tahun didapatkan hasil $R R<1 \quad(R R=0$ 0,828). Sehingga dapat disimpulkan bahwa risiko terjadinya preeklampsia/eklampsia pada kelompok usia $<20$ tahun lebih kecil dibandingkan dengan kelompok usia 20-35. Hal ini sesuai dengan penilitian yang dilakukan oleh Selvi Destaria, 2011. Didapatkan hasil tidak ada hubugan bermakna antara kejadian preeklampsia dengan kehamilan di usia muda. Hasil yang sama terjadi pada penelitian yang dilakukan oleh Candra, 2012 yang mengungkapkan bahwa usia $<20$ tahun bukan merupakan faktor risiko terjadinya preeklampsia/eklampsia. Hal yang sama juga diungkapkan oleh Fleming, 2013 hasil penelitain ini menyebutkan bahwa risiko preeklampsia/eklampsia pada usia $<20$ tahun sama dengan kelompok usia $>20$ tahun. Hal ini bertolak belakang dengan penelitian yang dilakukan oleh Tebeu, 2011 di Maroua Regional Hospital, Cameroon yang menemukan bahwa kehamilan pada usia muda berhubungan dengan peningkatan preeklampsia/eklampsia dalam kehamilan. Hasil yang sama juga diungkapkan oleh Saftlas pada tahun 1990 yang menyatakan bahwa wanita usia 15-19 tahun memiliki 2,6 kali risiko lebih tinggi terjadi preeklampsia/eklampsia dibandingkan dengan wanita usia 20-34 tahun. Hasil penelitian ini juga bertolak beakang dengan penelitian yang dilakukan oleh Rozikhan, 2007 yang dilakukan di Rumah Sakit Dr. H. Soewondo Kendal disimpulkan ada perbedaan proporsi terjadinya preeklampsia antara umur $20-35$ tahun dengan umur $<20$ tahun. Dan didapatkan nilai OR yang besarnya 3,58 yang artinya ibu yang hamil pada umur $<20$ tahun mempunyai risiko terjadi preeklampsia 3,58 kali dibandingkan ibu hamil yang berumur 20 - 35 tahun.

Pada penelitian ini, di kelompok usia $>35$ tahun didapatkan hasil $\mathrm{RR}=0322$ jika dibandingkan dengan usia $20-35$ tahun dan $\mathrm{RR}=0389$ jika dibandingkan dengan usia $<20$ tahun. Sehingga dapat disimpulkan bahwa risiko terjadinya preeklampsia/eklampsia pada kelompok usia $>$ 35 tahun lebih besar dibandingkan dengan kelompok usia 20-35 tahun dan kelompok usia $<20$ tahun. Hal ini sesuai dengan hasil penelitian yang dilakukan oleh Nojomi, 2010 yang dilakukan di Akbar-Abadi Hospital Iran dengan membandingkan wanita pada usia $>35$ tahun dengan wanita dengan usia lebih muda terhadap kejadian preeklampsia/ eklampsia. Wanita $>35$ tahun meningkatkan persentase preeklampsia/eklampsia (18.8\% vs $9.6 \%)$ dibandingan dengan wanita dengan usia $<35$ tahun. Nojomi mengatakan bahwa prevalensi preeklampsia/eklampsia meningkat seiring 
dengan peningakatan usia dan berhubungan dengan kerusakan endotel vaskular yang muncul dalam proses penuaan. Menurut hasil penelitian yang dilakukan Rahadian pada tahun 2011 di RSUP Dr. Kariadi Semarang didapatkan hasil kejadian Preeklampsia pada ibu usia $>35$ tahun ditemukan 22 subyek (36\%) pada ibu usia reproduksi (2035) ditemukan 5 subyek (8\%), hasil uji Chi-suare menunjukkan $\mathrm{p}=0,000$ berarti terdapat perbedaan yang bermakna dari kejadian preeklampsia yang menunjukkan ibu usia tua lebih banyak mengalami preeklampsia dibanding ibu usia reproduksi. Hasil penelitian ini bertolak belakang dengan penelitian yang dilakukan oleh Rozikhan, 2007 yang dilakukan di Rumah Sakit Dr. H. Soewondo Kendal. Berdasarkan hasil Uji statistik chi-square Pada usia $>35$ tahun diperoleh nilai $\mathrm{p}=0,059$. Sehingga dapat disimpulkan bahwa tidak ada hubungan secara signifikan antara kehamilan umur $>35$ tahun dengan terjadinya preeklampsia.

Selain bertujuan untuk mengetahui hubungan usia ibu hamil berisiko dengan preeklampsia/eklampsia, penelitian ini juga memiliki tujuan khusus. Yaitu untuk menganalisis hubungan paritas dengan kejadian preeklampsia/eklampsia pada ibu hamil usia $<20$ tahun dan $>35$ tahun serta ibu hamil usia 20-35 tahun. Paritas adalah salah satu faktor risiko preeklampsia/eklampsia. Frekuensi terjadinya lebih tinggi pada nullipara dibanding pada multipara. Berdasarkan teori imunologik, hal ini dikarenakan pada kehamilan pertama terjadi blocking antibodies terhadap antigen yang tidak sempurna. Selain itu, pada kehamilan pertama terjadi pembentukan Human Leucocyte Antigen Protein G (HLA) yang berperan penting dalam modulasi sistem imun, sehingga terjadi penolakan terhadap hasil konsepsi sehingga terjadi preeclampsia/ eclampsia. Pada kehamilan berikutnya, pembentukan blocking antibodies akan lebih sempurna akibat respon imunitas pada kehamilan sebelumnya sehingga risiko terjadinya preeklampsia/eklampsia pada multipara akan lebih rendah dibandingkan dengan nullipara.

Pada pengujian dengan analisis Chi-Square pada kelompok usia berisiko ( $<20$ tahun dan $>35$ tahun) didapatkan nilai $\mathrm{p}=0.022$. Nilai ini lebih kecil dari $\alpha=0.05$ dengan nilai korelasi -0,236 sehingga dapat disimpulkan bahwa terdapat hubungan yang bermakna antara paritas dengan kejadian preeklampsia/eklampsia. Semakin tinggi paritas maka semakin tinggi pula peluang mengalami preeklampsia/eklampsia. Hasil penelitain ini sesuai dengan penelitian yang dilakukan oleh Punyatoya, 2013 . Berdasarkan penelitian didapatkan 73 wanita nullipara (59.8) mengalami preeklampsia/eklampsia dan 76 (62.3) normal. Sedangkan pada wanita multipara didapatkan 49 wanita (40.2) menderita preeklampsia/eklampsia dan 46 wanita (37.7) normal. Sehingga berdasarkan hasil perhitungan statistik didapatkan nilai $\mathrm{OR}=0.90$ yang berarti peluang terjadinya preeklampsia/ eklampsia pada kelompok nullipara lebih kecil dibandingkan dengan kelompok multipara. Hasil penelitian ini tidak sesuai dengan penelitian yang dilakukan oleh Luealon pada tahun 2010 di Thailand. Pada penelitian tersebut didapatkan bahwa terdapat hubungan antara paritas dengan kejadian preeklampsia/eklampsia. Pada penelitian ini disebutkan bahwa wanita nullipara memiliki risiko 3,8 kali mengalami preeklampsia/eklampsia dibandingkan dengan wanita multipara. Luelalon menyebutkan bahwa tingginya risiko preeklampsia/eklampsia pada nullipara berhubungan dengan mekanisme imunologi terhadap paparan pertama pada trofoblas. Hasil penelitian ini memiliki nilai signifikasi yang sama dengan hasil penelitian sebelumnya. Akan tetapi, jika dilihat dari nilai korelasi yang bernilai negatif (-), terjadi perbedaan makna hubungan dengan penelitian sebelumnya. Pada penelitian sebelumnya menyimpulkan bahwa terdapat hubungan yang signifikan antara paritas dengan kejadian preeklampsia/eklampsia. Wanita nullipara lebih berisiko mengalami preeklampsia/eklampsia dibandingkan dengan wanita multipara. Hasil pada penelitian ini juga menyimpulkan bahwa terdapat hubungan yang bermakna antara paritas dengan preeklampsia/eklampsia. Semakin tinggi paritas makan peluang mengalami preeklampsia/ eklampsia juga meningkat. Dengan kata lain, wanita multipara lebih berisiko mengalami preeklampsia/eklampsia dibandingkan dengan wanita nullipara.

Perbedaan hasil penelitian ini dengan penelitian sebelumnya dapat disebabkan karena jumlah responden yang menderita preeklampsia/eklampsia dalam penelitian lebih banyak pada kelompok usia $>35$ tahun dibandingkan pada kelompok usia $<20$ tahun. Kelompok usia $>35$ tahun didominasi oleh wanita dengan status multipara yaitu sebanyak 25 wanita (51\%) dari total 47 wanita. Sedangkan pada kelompok usia $<20$ tahun didominasi oleh wanita nullipara yaitu sebanyak 4 wanita $(80 \%)$ dari total 5 wanita.

Sedangkan pengujian dengan analisis Chi-Square pada kelompok usia reproduksi sehat (20 - 35 tahun) didapatkan nilai $\mathrm{p}=0,371$. Nilai ini lebih besar dari $\alpha=0,05$. Sehingga dapat disimpulkan bahwa tidak terdapat hubungan yang bermakna antara paritas dengan kejadian preeklampsia/ eklampsia. Hal ini sesuai dengan penelitian yang dilakukan oleh Nuryani, 2013 di RSUP Wahidin Sudirohusodo, Makassar, hasil tidak terdapat hubungan yang bermakna antara paritas dengan kejadian preeklampsia/eklampsia. Hasil yang sama juga terdapat pada penelitian Jumaila, 2000 di tempat yang sama Demikian pula dengan hasil penelitian Artikasari, 2009 di RSUD Moewardi Surakarta yang menyebutkan bahwa wanita nullipara hanya memiliki risiko 1,458 kali untuk mengalami preeklampsia/eklampsia dibanding dengan wanita bukan nullipara. Berdasarkan penelitian yang dilakukan Jasovic-sivesca, 2011 didapatkan nilai $\mathrm{p}>0.05$. Penelitian tersebut dilakukan dengan membagi responden ke dalam 4 kelompok. Yaitu primipara, secondarypara, tertipara dan multipara ( $>3 \mathrm{x}$ kehamilan). Berdasarkan hasil analisis regresi logistik didapatkan pada primipara nilai $\mathrm{p}=0.38$ dan $\mathrm{OR}=0,61$. Sedangkan untuk multipara didapatkan nilai $\mathrm{p}=0.29$ dan $\mathrm{OR}=0.40$. Sehingga dapat disimpulkan bahwa tidak terdapat hubungan yang bermakna antara paritas dengan kejadian preeklampsia/ eklampsia. Hasil penelitian ini bertolak belakang dengan hasil penelitian yang dilakukan oleh Rahayu, 2012 di RS Syaiful Anwar Malang dengan nilai $p=0.000(p<0.05)$ dan Sultana, 2013 dengan nilai $p=0.001(p<0.05)$. Sedangkan berdasarkan hasil penelitian yang dilakukan oleh Candra, 2012 didapatkan nilai $\mathrm{p}=0.000$ dan $\mathrm{RR}=2.223$. Sehingga dapat disimpulkan bahwa terdapat hubungan yang bermakna antara paritas dengan kejadian preeklampsia/eklampsia dan wanita primipara berisiko 2,223 kali lebih besar mengalami 
preeklampsia/eklampsia dibandingkan dengan wanita multipara. Hal yang sama juga diungkapkan oleh Hernandez, 2010 yang menyebutkan bahwa risiko terjadinya preeklampsia adalah $4,1 \%$ pada nullipara dan $1,7 \%$ pada multipara.

Terjadinya perbedaan hasil penelitian ini dengan hasil penelitian sebelumnya dapat dikarenakan adanya perbedaan pengklasifikasian responden berdasarkan paritas. Selain itu dapat dikarenakan adanya perbedaan situasi dan keadaan baik jumlah dan distribusi pasien, lokasi dan waktu antara penelitian sebelumnya dengan penelitian ini. Hasil suatu penelitian hanya dapat berlaku pada situasi dan keadaan yang sesuai situasi dan keadaan dimana penulisan tersebut dilakukan (Basuki, 2006).

\section{KESIMPULAN}

Berdasarkan hasil penelitian yang telah dilakukan di RSU Haji Surabaya dapat disimpulkan terdapat hubungan yang bermakna antara usia ibu hamil berisiko $(<20$ tahun dan $>35$ tahun) dengan kejadian preeklampsia/eklampsia di RSU Haji Surabaya periode 01 Januari 2013 - 31 Desember 2013, distribusi angka kejadian preeklampsia/eklampsia berdasarkan usia ibu hamil di RSU Haji Surabaya Periode 01 Januari 2013-31 Desember 2013 adalah pada kelompok usia $<20$ tahun sebanyak 5 wanita $(3,8 \%)$, Pada kelompok usia 20-35 tahun sebanyak 76 wanita (59\%), dan pada kelompik usia $>35$ tahun sebanyak 48 wanita $(37,02 \%)$, hasil analisis perhitungan Relative Risk didapatkan $\mathrm{RR}>1 \quad(\mathrm{RR}=2,146)$ sehingga dapat disimpulkan bahwa kelompok usia ibu hamil berisiko $(<20$ tahun dan $>35$ tahun) lebih berisiko mengalami preeklampsia/eklapmsia dibandingkan dengan kelompok usia 20-35 tahun, dan terdapat hubungan yang bermakna antara paritas dengan kejadian preeklampsia/ eklampsia pada ibu hamil usia berisiko ( $<20$ tahun dan $>35$ tahun) dan tidak terdapat hubungan yang bermakna antara paritas dengan kejadian preeklampsia/eklampsia pada ibu hamil usia reproduksi sehat (20-35 tahun) di RSU Haji Surabaya periode 01 Januari 2013-31 Desember 2013.

\section{DAFTAR PUSTAKA}

Anderson, NH., LME, McClown., EM, Fyfe. 2012. The Impact of Maternal Body mass Index on The Phenotype pf Pre-eclampsia: A Prospective Cohort Study. BJOG An International Journal of Obstetric and Gynaecology :4-6.

Bramham K, Amehel, Briley, Paul S. 2011. Adverse Maternal And Perinatal Outcomes In Women With Previous Preeclampsia : A Prospective Study. American Jurnal Obstetrics 204 : 512-513.

Casey, E., Hayes, N., Ross, A. 2013. Obstetric Critical Care. An ESICM Mulitidiciplinary Distance Learning Programme For Intensive Care Training. The Mercy Hospital. Melbourne.

Candra, Siti., Setijowati, N., Soraya, D. 2012. Hubungan Usia dan Paritas Dengan Kejadian Preeklampsia di Rumah Sakit Dr. Saiful Anwar Malang Tahun 2012. Malang.

Charlish, Anne., Davies, K. 2005. Meningkatkan Kesuburan Untuk Kehamilan Lamai. Jakarta: ESENSI, PP.44

Cunningham et all : alih bahasa, Andry Hartono, Y. Joko Suyono, Brahm U. Pendit; editor edisi bahasa Indone- sia, Huriawati Hartanto et all. Ed 23, 2012, Obsteri Williams, Ed.21, Vol 1, EGC, Jakarta. Bagian VII hal 624-651.

Departemen Kesehatan RI. Riset Kesehatan Dasar (RISKESDAS), laporan nasional 2010. Jakarta: Departemen Kesehatan RI; 2010.

Dharma R, Noroyono Wibowo, Hessyani.2005. Disfungsi Endotel Pada Preeklampsia. Makara Kesehatan 9 (2) : 63-65.

Dinas Kesehatan.2013.Profil Kesehaan Provinsi Jawa Timur. Surabaya.

Direktorat Bina Kesehatan Ibu Ditjen Bina Gizi dan Kesehatan Ibu dan Anak, Kementrian Kesehatan RI. 2011. UPAYA PERCEPATAN PENURUNAN ANGKA KEMATIAN IBU. FACTSHEET. Jakarta.

Djannnah, S., Arianti, I. 2010. Gambaran Epidemiologi Kejadian preeklampsia/Eklampsia di RSU PKU Muhammadiyah Yogyakarta tahun 2007-2009. Buletin Sistem Kesehatan 13(4): 378-385.

Fleming N, Natalia Ng, Christine Osborne, Shawna Bierderman, Abdool Shafaaz. 2013. Adolescent Pregnancy Outcomes In The Province Of Ontario : A Cohort Study. J Obstet Gynaecolcan 35 (3) : 235-236.

Gilbert,Elizabeth. 2011. Manual of High Risk Pregnancy and Delivery. 5th Edition. Mosby Elsevier. Arizona. Unit V page 416 - 423 .

Haldre K, Rahu K, Karro H, Rahu M. 2007. Is a poor pregnancy outcome related to young maternal age? A study of teenagers in Estonia during the period of major socio-economic changes (from 1992 to 2002). Eur J Obstet Gynecol Reprod Biol 2007;131:45-51.

Indumati K, Kodliwadmath MV and Sheela MK. 2011. The Role of serum Electrolytes in Pregnancy Induced Hypertension. Journal of Clinical and Diagnostic Research 5(1): 66-69.

Jasovic-siveska, E., Jasovic, V., Stoilova, S. 2011. Previous Pregnancy History, Parity, Maternal Age dan Risk of Pregnancy Induced Hypertension. Bratisl Lek Listy 112(4): 188-191.

Kazemian, E., Ahmad, M., Gity, S., Mohammad, R., Samareal, A. 2012. Nutritional Status of Women With Gestasional Hypertension Compared to Normal Pregnant Women. Women's Health Care 1(10): 1-4.

Luealon, P., Phupong, V. 2010. Risk Factor of Preeclampsia in Thai Women. JMed Assoc Thai 93(60: 661.

Manuaba, I.B.G. 2012. Pengantar Kuliah Obstetri. Jakarta : EGC. BAB 6 hal. $401-431$.

NHSCB.2013. Clinical Commissioning Policy : Complex And Specialised Obesity Surgery. Cetakan 1. NHS Commissioning Board.

Nojomi, M., Ladan, H, Bita, B., Layla, R., Sayede, K. 2010. Delayed Childbearing: Pregnancy and Maternal Outcomes. Iranian Journal of Reproductive Medicine 8(2): 80-81.

POGI, IDAI, IDI, IKABI, Bakti Husada. 2010. Buku Panduan Praktis Pelayanan Kesehatan Maternal dan Neonatal. Cetakan ke dua belas. PT Bina Pustaka Sarwono Prawirohardjo. Jakarta.

Prawirohardjo, Sarwono. 2010. Ilmu Kebidanan Edisi III , Yayasan Bina Pustaka Sarwono Prawirohardjo, Jakarta. Bagian III Pp 530 - 555. 
Prianita, A. 2011. PENGARUH FAKTOR USIA IBU TERHADAP KELUARAN MATERNAL DAN PERINATAL PADA PERSALINAN PRIMIGRAVIDA DI RS DR. KARIADI SEMARANG ERIODE TAHUN 2010. Skripsi. Program Studi Pendidikan Sarjana Kedokteran Universitas Diponegoro. Semarang.

Punyatoya, Bej., Pragti, C., Shama K., Guleria, K. 2013. Deetermination of Risk Factors for Preeclampsia and Eclampsia in a tertiary hospital of India : A Case Control Study. Journal of Family Medicine and Primary Care 2(4) : 372-374.

Quzi G. 2011. Obstetric Characteristics And Complications Of Teenage Pregnancy. JPMI 25 (02) : 134-135.

Rahayu, Indra Dewi. 2012. Hubungan Usia Dan Paritas Dengan Kejadian Preeklampsia Di Rawat Inap SMF Obstetri Ginekologi RSU Dr. Saiful Anwar Malang. Skripsi. Program Studi Pendidikan Dokter, Universitas Brawijaya. Malang.

Roten L. 2009. Genetic Predisposition For Development Of Preeclampsia. Philosophiae Doctor. Nowegian University Of Science And Technology. Norwegia.

Rozanna. F., R., Dawson, A., Lohsoonthorn, V., \& Williams, M.A. (2009). Risk Factors of Early and Late Onset Preeclampsia among Thai Women. Journal Medical Assocciation. 3(5): 477486.

Rozikhan. 2007. FAKTOR-FAKTOR RISIKO TERJADINYA PREEKLAMPSIA BERAT DI RS Dr. H SOEWONDO KENDAL. Tesis. Program Studi Magister Epidemiologi Universitas Diponegoro. Semarang.

Saftlas, A., Olson, D.R., Franks, A.L., Atrash, H.K., Pokras, R. 1990. Epidemiology of preeclampsia and eclampsia in the United States, 1979-1986. Am J Obstet Gynecol 163(2):460-5.

Sayyed, A., Sonttake, A. 2013. Electrolyte Status in Preeclampsia. Interdiciplinary Research journal 3(3): 31-35.

Shamsi, U., Saleem, S., Nishter, N. 2013. Epidemiology and Risk Factors of Preeclampsia ; an Overview of Observational Studies. Al Ameen J Med Sci 6(4): 292-300.

Sibai BM.2011. Etiology and Management Pf Postpartum Hypertension-Preeclampsia. American Jurnal Of Obstetrics \& Gynecology : 470-472.

Sibolon,D.,Ainin,N. 2013. Kehamilan Usia Remaja Prakondisi Dampak Status Gizi Terhadap Berat Lahir Bayi Di Kabupaten Rejang Lebong Propinsi Bengkulu. Prosiding Seminar Nasional Kependudukan Jember. Universitas Jember: 32-34.

Simbolon, S., Meilany, D., Poppy, L. 2013. GAMBARAN HISTOPATOLOGI PLASENTA PADA KEHAMILAN DENGAN PREEKLAMPSIA. Jurnal e-Biomedik (eBM) 1(2): 2-4.

Tebeu, P., Foumane, P., Mbu, R., Fosso, G., Biyaga, P., Fomulu, J. 2011. Risk Factor for Hypertensive Disorders in Pregnancy: A Report from Moroua Regional Hospital, Cameroon. J.Reprod Infertil 12(3): 227-234.

The American College Of Obstetricians and Gynecologists.2013. Hypertension in Pregnancy. Washington.

Utama, Y.S. (2008). Faktor Risiko Yang Rerhubungan Dengan Kejadian Preeklampsia Berat Pada Ibu Hamil Di RSD Raden Mataher Jambi. Jurnal Ilmiah Universitas Batanghari Jambi 8(2): 2-4.
Uzan, J., Marie, C., Oliver, P., Roland, A., Jean-Marc, A., 2011. Pre-eclampsia : Pathophysiology, Diagnosis, and Management. Vascular Health and Risk Maagement (7): 467-473.

WHO. Adolescent Pregnancy: issues in adolescent health and development. Jenewa. 2013. http://www.who.int/ maternal_child_adolescent. Diakses tanggal 10 desember 2013.

Winarsi, H., Alice, Y., Agus, P., 2013. Deteksi Aging Pada Perempuan Berdasarkan Status Antioksidan. $M K B$ 45(3): 142.

Zubaidi, R. 2011. PERBANDINGAN LUARAN MATERNAL DAN PERINATAL IBU USIA TUA DENGAN USIA REPRODUKSI. Skripsi. Program Studi Pendidikan Sarjana Kedokteran Universitas Diponegoro. Semarang. 